\title{
Norm Robustness and Contestation in International Law: Self-Defence against Non- State Actors
}

\section{Jutta Brunnée and Stephen J Toope}

\author{
Version Post-print/accepted manuscript \\ Citation Brunnée, Jutta and Toope, Stephen J., Norm Robustness and \\ (published version) Contestation in International Law: Self-Defence against Non-State \\ Actors (May 15, 2017). Available at SSRN: \\ http://dx.doi.org/10.2139/ssrn.2985655
}

How to cite TSpace items

Always cite the published version, so the author(s) will receive recognition through services that track citation counts, e.g. Scopus. If you need to cite the page number of the author manuscript from TSpace because you cannot access the published version, then cite the TSpace version in addition to the published version using the permanent URI (handle) found on the record page.

This article was made openly accessible by $U$ of $T$ Faculty. Please tell us how this access benefits you. Your story matters. 


\title{
Norm Robustness and Contestation in International Law: Self-Defence against Non-State Actors
}

\author{
CJutta Brunnée and Stephen J. Toope
}

\section{Introduction}

Back in the 1920s, the great US legal scholar Roscoe Pound argued that "[I]aw must be stable and yet it cannot stand still. Hence all thinking about law has struggled to reconcile the conflicting demands of the need of stability and the need of change" (Pound 1923). Understanding the fluid interactions of stability and change has been a constant preoccupation in law, including international law. Strikingly similar preoccupations figure prominently in the International Relations (IR) literature on norm robustness. In this essay we link these inquiries in international law and IR and show that understanding the distinctiveness of legal norms can help us understand the concept of "robustness" as described by the framers of this special issue. What is more, because "contestation" is a central feature of law, especially what Zimmermann and Deitelhoff call "applicatory contestation" (Zimmermann and Deitelhoff 2016), we think that there is much to be learned about the role of norm contestation through examining the emergence, stabilization and decay of legal norms.

In the IR literature on norm robustness, it is commonly assumed that all norms are either in the process of construction or destruction, are being built or are decaying. (Sandholtz 2009) The experience of international law reveals that another process is also possible: the stabilizing or maintenance of a norm through the dynamics of daily contestation and reconstruction, through what we call "practices of legality." The closest parallel in IR thinking is Sandholtz's marvellous description of norms as "moving pictures," made up of thousands of frames, micro patterns of challenge and reinforcement (Sandholtz 2009). International law illustrates that contestation is inherent in normativity (Wiener 2014), and that it can build, sustain, change or destroy norms, depending upon the nature and extent of the contestation. In this sense, we agree with Zimmermann and Deitelhoff that contestation is a continuum and that it is important to distinguish between applicatory and validity contestation.

Our goal in this paper is to deploy our interactional understanding of international law to examine processes of contestation and their role in challenging, but also supporting, legal norms. We will argue that although validity contestation is rare in law, applicatory contestation is inevitable. Most legal norms are refined or challenged in their application through processes of interpretation and justification. This constant, typically incremental contestation tends to 
reduce the pressure for validity contestation, and helps to account for the robustness of law, and its capacity to provide stability. We will illustrate this dynamic through a close examination of the inter-state legal framework on the use of force. This framework is particularly instructive because it encompasses treaty norms, found in the UN Charter, that are also closely tied, and indeed subject to, development through customary international law.

We focus specifically on contestation surrounding the right to self-defence against non-state actors, and show that applicatory contestation of legal norms is disciplined through specific requirements of legality. Furthermore, engaging with self-defence requires us to consider the primary norm of the framework: the prohibition on the use of force. It is only against this general prohibition that one can consider exceptional circumstances in which states are permitted to use force, including the right to self-defence against non-state actors. We will demonstrate that, from a legal standpoint, certain forms of applicatory contestation in relation to the right to self-defence amount to indirect validity contestation of the prohibition on the use of force. However, the primary norm is actually very strong. Therefore challenges to its validity are resisted, which means that the scope for applicatory contestation of the right to self defence is constrained. This rule-exception dynamic is central to the legal assessment of both material and rhetorical practices that shape the right to self-defence against non-state actors.

\section{What is a Legal Norm?}

In the broadest terms, "norms" are standards of behavior created through mutual expectation in a social setting. Social norms are grounded in an underlying set of shared understandings supporting first the need for normativity, and then particular norms that shape behavior. Shared understandings can emerge, evolve or fade through processes of social interaction and social learning (Brunnée and Toope 2010, 56-65). Once in existence, shared understandings become norms that shape how actors perceive themselves and the world, how they form interests and set priorities, and how they make or evaluate arguments.

The category of "legal norm" is not firmly fixed. What norms will be included in the category depends on one's concept of law. For example, legal theorists called "pluralists" see no significant distinction between "law" produced by state authorities and norms created by voluntary associations; several different legal orders may co-exist (Berman 2012; Bianchi 2016). For these pluralist theorists, it is Zimmermann and Deitelhoff's concept of "facticity" that is the key to understanding "law." Does it actually cause behaviour (Zimmermann and Deitelhoff 2016)? The pedigree or origin of "law" is, for legal pluralists irrelevant; as long as the norm has concrete effects, and shapes communities, it is "law." 
By contrast, the still-dominant "positivist" stream of legal theory asserts that legal norms only exist when they are produced through pre-established institutional hierarchies, usually state hierarchies (Kammerhofer 2015; Bianchi 2016). It is their formal pedigree that creates legal norms; therefore law exists whether or not it links to social norms. For positivists, validity is a formal concept relating to the mode of production of the norm; it does not relate to the "widespread acceptance" that Zimmermann and Deitelhoff describe (Zimmermann and Deitelhoff 2016). However, even positivists would agree that international legal norms cannot be identified simply by looking at a text, and legal change is not brought about only through formal processes that amend the text. This point is obvious in the context of customary international law, but applies also to treaty law. Ultimately, international practice importantly, including both material and rhetorical acts (interpretation, argumentation and justification) - is what makes, maintains, changes, and destroys international law (Brunnée and Toope 2010; 2011).

Over the last twenty years, we have developed this insight and have articulated an understanding of how legal norms operate in international society that we call "interactional international law" (Brunnée and Toope 2010; 2011). This framework refuses to accept the polarity of pluralism and positivism. We argue that all legal norms are embedded in, and must be broadly in line with, social norms that arise from the practices and understandings of the society in which they operate (Postema 1994; Reinold and Zürn, 2014). For us, Zimmermann and Deitelhoff's version of validity (as distinct from a legal positivist understanding) matters. ${ }^{1}$ However, we stress that shared understandings (social acceptance or "validity") alone do not make law. Nor can the existence of law be assessed simply against its effects ("facticity"). Many social norms exist that never reach the threshold of legal normativity, and legal norms can survive significant violations. What distinguishes legal norms from other types of social norms is not widespread social acceptance alone; nor is it form or pedigree, but adherence to criteria of legality. The most commonly referenced legality criteria were proposed by Lon Fuller (1969), and we use them as shorthand for "legality" because of their clarity and cogency. They are central to every effort to define the "rule of law" and they capture distinctive traits of legal practice (Brunnée and Toope 2017).

For Fuller, legal norms (rooted of course in social norms) must be general, providing rules, rather than ad hoc decisions that prohibit, require or permit certain conduct. They must also be promulgated, and therefore accessible to the public, enabling actors to know what the law requires. Law should not be retroactive, but prospective, enabling citizens to take the law into account in their decision-making. Actors must also be able to understand what is permitted,

\footnotetext{
${ }^{1}$ Throughout the remainder of the paper, we will use the term "validity" in the sense ascribed to it by the framing paper.
} 
prohibited or required by law - the law must be clear. Law should avoid contradiction, not requiring or permitting and prohibiting at the same time. Law must be realistic and not demand the impossible. Its demands on citizens must remain relatively constant. Finally, there should be congruence between legal norms and the actions of officials operating under the law (Fuller 1969: 46-91) and, as a result, a "stable reciprocity of expectations between lawgiver and subject" (Fuller 1969: 209).

"Reciprocity" is central to the interactional account of international law. It reveals that law cannnot be a one-way street, a mere imposition of power or even authority. We believe that reciprocity is deeper than the exchange flowing from the calculation of material interests (Brunnée and Toope 2010: 37-42). When actors in the system believe that their interactions are shaped by reciprocal commitment to the requirements of legality, law will tend to attract its own adherence - an internalized sense of "obligation" will have been created. Hence the criteria of legality are not merely "signals" to actors, but are internal conditions for the existence of law. They go beyond both validity and facticity. We therefore disagree with Hurd who suggests that norms need only be widely ratified and widely used rhetorically - an entirely political view of normativity (Hurd 2014, 172). For legal norms, the criteria of legality impose a further discipline that is internal to law. So it is not true that "one actor's compliance is another actor's non-compliance" (Hurd 2014, 167-68, 183). It is often possible, in law, to know whether or not an argument on compliance is convincing by testing it against the criteria of legality.

When social norm creation meets the criteria of legality, and when there exist what we call continuing "practices of legality," actors can pursue their purposes and effectively organize their interactions through law. A particular legal instantiation of the idea of communities of practice (Wenger, 1998; Adler, 2005), therefore, completes our understanding of the relationship between shared understandings and the criteria of legality. Interactional law does not arise simply because a community of practice has grown around a given issue or norm. Only when this community engages in practices of legality, continually testing social norms against the requirements of legality, can legal norms be produced, maintained or altered. This "testing" takes place both through rhetorical and material practices of norm application, including processes of implementation, interpretation, justification, and enforcement. Such practices of legality are crucial to generating distinctive legal legitimacy and the aforementioned sense of obligation, "fidelity" in Fuller's terms (Fuller 1969: 39-41), among those to whom law is addressed. These practices of legality are more than mere "compliance" (conformity of behaviour to a rule), and they can exist without "enforcement."

The operation of practices of legality is especially evident in customary international law. Our approach connects to that of Richard Price $(2004,2006)$ and Sandholtz $(2009 ; 2016)$, who 
evaluate norm robustness through the processes of claim and contestation around customary legal norms. It builds as well on the insights of Kratochwil and Ruggie who argue that "whether or not violations also invalidate or refute a law (norm) will depend on a host of factors, not the least of which is how the community assesses the violation and responds to it" (Kratochwil and Ruggie 1986, 767). Our interactional approach helps explain the strange, even "mysterious" (Koskenniemi 2011), requirement of customary international law that one must prove opinio juris, the subjective belief that a practice is required by law. Instead of simply counting up state practice around a given norm and assuming opinio juris, as is the unarticulated approach of many international lawyers, we suggest that opinio juris is best understood as the need to test subsequent practices surrounding a given legal norm against the criteria of legality. Put differently, the practices of legality are evidence of opinio juris.

For that special category of norm that we call "law," we describe a particular "life cycle" that explains why a norm cascade may happen, how stability or robustness can be achieved and why a reverse cascade is also possible (Finnemore and Sikkink 1998; Panke and Petersohn 2012). Legal norms are built and maintained through validity, the instantiation of criteria of legality, and facticity over time - comprising both practice and continuing commitment to the criteria of legality ("practices of legality"). When elements converge, an internal sense of obligation is created that makes law "binding" on all actors in the society.

However, the criteria of legality do not operate like an on-off switch. They help us understand why, in the words of the framing paper, robustness of norms exists along a continuum. A given norm may be more or less clear, more or less constant. The congruence required between a norm and its practical application may be imperfect. For that reason, law is not static. It is possible for a norm to be "becoming" law or "failing to be" law. All law is dynamic, each norm made up of the thousands of moving frames that Sandholtz imagined. So simply institutionalizing a norm as formal law ("positing" the legal rule) does not necessarily strengthen the norm; nor does it guarantee its robustness over time (Percy 2014). A legal norm may be "valid" in a purely formal (positivist) sense, as agreed to even in a widely ratified treaty for example, but not be supported by sufficient shared understandings, or sufficiently meet the requirements of legality, to become or remain interactional law. In such cases, the norm will not generate the internal sense of obligation that engenders fidelity.

Certain of the criteria of legality also point to the central role of, even the need for contestation in law. That a legal norm should be general in application ensures that all actors in a society should care about the rule, enough to question its application in an individual case. The promulgation requirement allows for legal challenge; one cannot question a rule that one does not know exists. Clarity is a requirement for effective applicatory contestation for it is 
frustrating and often meaningless to argue over utterly opaque norms. Similarly, the demand that a legal norm be realistic encourages contestation over norms that are unduly taxing. Finally, the congruence requirement means that contestation is facilitated whenever a legal norm is not being applied by legal decision makers. In our case study of self-defence against non-state actors, we will show concretely how these criteria operate.

The last legality requirement, congruence in the positing of a norm and its application, connects to the continuing practice of legality that maintains or disrupts a legal norm. In a sense the practice of legality is a constant contestation over the appropriate application of a posited legal norm. If the norm comes not to meet the criteria of legality for any reason, such as its becoming impossible to fulfil due to fundamentally changed circumstances, or if it is simply ignored in practice, the norm may be effectively contested, and displaced or replaced by another norm.

The interactional approach to international law is a close-to-complete explanation of norm robustness in law. It explains how legal norms are constructed and what stabilizes them in a dynamic equilibrium. Further, the interactional approach illuminates the crucial role of contestation in legal normativity (Wiener 2004, 218). Legal norms arise from shared social understandings, and these understandings emerge through interaction in the socio-economicpolitical world. Understandings typically become "shared" only after processes of contestation allow them to be posited, challenged and argued over (Wiener 2014). However, we also show that applicatory contestation can become so severe as to undermine the criteria of legality, leading to a form of validity contestation and ultimately to the destruction of the legal norm.

A further point deserves brief development. Because law can only exist if the internal criteria of legality are continuously met, the effect of contestation in law is not determined primarily by relative material power. Powerful actors cannot simply manipulate the law as they see fit. They are actually constrained by law, notwithstanding their power (Sandholtz 2009). Of course, power matters; greater power may allow for more consistent and widespread contestation. However, if a powerful actor attempts to construct a norm that fails to meet the criteria of legality, the norm will not become law and will not partake of its special legitimizing quality that internal fidelity imparts (Brunnée and Toope 2017). These issues will be addressed directly in our case study.

With our interactional international law framework in mind, we now turn to our case study to show how the robustness of legal norms can be explained and assessed. We briefly introduce the legal framework on the use of force, and sketch the evolution of debates surrounding selfdefence against non-state actors. We then examine this evolution through the lens of 
interactional law, tracing out the role of both validity and applicatory contestation in the processes that create, sustain or breed decay in fundamental legal norms.

\section{Legal Norms on Self-Defense against Non-State Actors}

The international legal framework on the recourse to armed force consists of the prohibition on the inter-state use of force, existing in customary law and enshrined in Article 2(4) of the UN Charter, and two exceptions to this primary rule: authorization of force by the UN Security Council under Chapter VII of the UN Charter, and self-defence against armed attacks under customary law and enshrined in Article 51 of the Charter. These components of the normative framework are tightly interwoven.

The prohibition on the use of force could not exist without exceptions. This point is an immediately obvious one in practical terms. Using the interactional international law framework, we will show why it also holds true in legal terms. Another dimension of the close connections between the prohibition and the exceptions is that changes in one of the salient norms affect the others. For example, the less Chapter VII's collective security system is able to address threats to and breaches of international peace and security, the more (practical and normative) pressure there is to expand the scope of states' right to self-defence. In turn, the more broadly the right to self-defence is construed, the more it trenches on the normative space occupied by the prohibition on the use of force.

We argue that an appreciation of the interplay between the prohibition on the use of force and the right to self-defence is crucial to understanding the relative robustness of the latter, the role of contestation, and the dynamics that lead to norm change in law. We will show why, from a legal standpoint, certain forms of applicatory contestation in relation to the right to selfdefence amount to indirect validity contestation of the prohibition on the use of force. Yet, since the prohibition on the use of force itself is not today subject to direct validity contestation (and indeed, even applicatory contestation has subsided), the normative strength of the prohibition serves to constrain expansive forms of applicatory contestation concerning the selfdefence norm. Our interactional account of international law, with its focus on the interplay amongst shared normative understandings, the requirements of legality, and practices of legality, provides a finely grained analytical framework for illuminating these dynamics.

For the purposes of this paper, we focus on the right to use force in self-defence. The existence of the right is uncontested. However, self-defence has been subject to long-standing, vigorous applicatory contestation, much of which has centered on what constitutes an "armed attack" 
that would trigger the right. ${ }^{2}$ There are several inter-related strands to this debate: when is a use of force of sufficient gravity to amount to an armed attack; can the right to self-defence be exercised in advance of an armed attack; and can armed attacks that would trigger the right to self-defence be undertaken by non-state actors?

We examine the third of these strands of applicatory contestation, paying particular attention to the recent debates surrounding self-defence measures against the Islamic State (IS) in Syria. ${ }^{3}$ As we will show, the circumstances under which the actions of non-state fighters can be attributed to a state such that it would be exposed to lawful response action by the victim state have long been subject to debate. This debate assumed heightened importance after the terrorist attacks of 11 September 2001, and has taken center-stage since the rise of the IS network in Iraq and Syria.

We will illustrate that repeated cycles of contestation have resulted in a loosening of the attribution standards and, since 2001, in widespread acceptance that the right to self-defence can be exercised not only against armed attacks that are undertaken by, or attributable to a state, but also against terrorist attacks without state nexus. In the latter context, however, the circumstances under which armed response action can be taken in the territory of another state remain unsettled. While a number of states have advanced the proposition that such action is lawful when the relevant state is "unwilling or unable" to avert the threat emanating from terrorists operating in its territory, this approach is contested. Many states explicitly resist the formula, others are silent or ambiguous in their reactions, and a few states have advanced an alternative, narrower set of preconditions for lawful response action that may be gaining traction. We argue that the distinctive requirements of legality have played central roles in animating both the expansion of the right to self-defence in response to non-state actor attacks and the resistance to the "unwilling or unable" standard.

\subsection{Self-Defence against Non-State Actors: Legal Developments}

The UN Charter's use of force framework was a response to World War II and, therefore, enshrined rules that were "directed to inter-state conflict" (Gray 2008, 6; Corten 2010, 126 and 161). However, the text of Article 51 does not make reference to "states" as the origin of the "armed attack" that gives rise to the right to self-defence, and commentators have suggested that the pre-Charter history does not justify insistence on a strictly inter-state right to self-

\footnotetext{
${ }^{2}$ Other key debates, which we leave aside for present purposes, concern necessity and proportionality in the exercise of the right to self-defence (Gardham 2004).

${ }^{3}$ We use "IS" as shorthand for the various manifestations of the terror network also known as the "Islamic State in Iraq and the Levant" (ISIL) or "Da'esh."
} 
defence (Trapp 2015, 205). Some states and commentators began, as early as the 1960s, to assert that the "inherent" right of individual or collective self-defence could be exercised against non-state actor attacks, and in states that were harbouring the attackers (Ruys 2010, 400-401). Israel was the first state to assert, in the 1970s, that it could take self-defence measures in a state (Lebanon) that was "unwilling or unable" to prevent cross-border attacks on Israel emanating from its territory. These interventions, however, were denounced by the Security Council and rejected by many states, albeit for a variety of reasons unrelated to the non-state actor dimension (Ruys 2010, 402-404).

The controversy surrounding attacks by non-state actors, and any right of response, was highlighted in the course of the UN General Assembly's efforts to provide authoritative definitions of the use of force in the Friendly Relations Declaration (UNGA 1970). It came to a head in the Assembly's subsequent struggle to define "aggression," a notion that identifies one of the grounds for Security Council action under Chapter VII (UN Charter, Article 39), but is also seen as closely tied to the concept of armed attack in Article 51 (ICJ 1984, para. 195; Ruys 2010, 127-139). The General Assembly eventually found a compromise formula. Article 3(g) of the Definition of Aggression qualified the "sending by or on behalf of a State" of non-state forces as an act of aggression, along with situations involving a state's "substantial involvement" in the non-state attack (UNGA 1974). It is significant that even those states that had urged an expansive definition, accepted the premise that only attacks supported by states could amount to aggression (Ruys 2010, 131-132; 386-390).

The International Court of Justice (ICJ), in its landmark ruling in the Nicaragua case (ICJ 1984), built on the Friendly Relations Declaration and the Definition of Aggression to underscore that only attacks by a state, or attributable to a state, can trigger the right to use force in selfdefence. The Court took Article 3(g) of the Definition of Aggression as a statement of customary international law, but focused on the "sending" of irregular forces, requiring that the state had control over the armed operation (ICJ 1984, paras. 109, 195). In noting that various kinds of assistance to irregular forces might amount to illegal intervention or illegal use of force, but not an "armed attack," the Court read the "substantial involvement" aspect of Article 3(g) of the Definition of Aggression narrowly. Although some commentators and even some judges sitting on the Court criticized this approach as unduly restrictive of the right to self-defence (Zemanek, 2013), the ICJ reaffirmed the narrow construction of the right to self-defence against non-state actor attacks in several subsequent decisions (ICJ 2004, 2005, 2007).

However, with the rise of international terrorism in the 1980s, the United States began to assert a broader right to self-defence. Initially it relied primarily on wider tests for state involvement, but, beginning in the 1990s, it advanced the "unwilling or unable" standard (Ruys 
2010, 421-433) - a standard that plainly did not meet even the most expansive reading of the "substantial involvement" criterion in the Definition of Aggression.

After the terrorist attacks of September 11, 2001, the issue of self-defence against non-state actor attacks rose to the top of the international agenda. The Security Council, in resolutions 1368 and 1373 (UNSC 2001a; 2001b), recognized "the inherent right of individual or collective self-defence," and in early October, NATO determined that its collective self-defence provision had been triggered by attacks "directed from abroad." In their letters to the Security Council indicating that they had begun self-defence operations in Afghanistan, the United States and the United Kingdom highlighted the support of Al-Qaeda by the Taliban regime (UNSC 2001c; 2001d). The international response to these operations was generally supportive, but international practice remained ambiguous, fitting narrower self-defence requirements or being accompanied by alternative justifications (Hakimi 2015; Tibori-Szabó 2015, 86).

The rise of the IS, a sophisticated, transnational terror network that exercises a degree of territorial control over parts of existing states, prompted states to take military actions in Iraq and Syria. The interventions by Western states in Syria are particularly relevant for present purposes, since they were undertaken under the banner of self-defence against IS, and in the absence of a link between the IS operations and the Syrian state. Furthermore, since military action is accompanied by explicit legal justifications, the operations against IS in Syria provide an opportunity to assess both material and rhetorical practices.

The focus of operations against IS was initially in Iraq, which had consented to international military action in its territory. In September 2014, the United States and a coalition of several other states began to strike IS in Syria (Starski 2016, 27), from where the network was planning and carrying out cross-border attacks in Iraq as well as other terrorist attacks. To find reliable evidence of the legal opinions of the intervening states, we use the official letters they sent to the Security Council, in keeping with their obligation under Article 51 of the UN Charter, to report that they had initiated self-defence measures. From a legal perspective these statements help us understand what the concrete actions (intervention) were meant to signify.

In its letter of September 2014 to the Security Council, the United States asserted that states "must be able to defend themselves, in accordance with the inherent right to individual and collective self-defence ... when ... the government of the State where the threat is located is unwilling or unable to prevent the use of its territory for ... [terrorist] attacks" (UNSC 2014a). With this statement, the United States unequivocally went beyond the Nicaragua case and the Definition of Aggression, asserting that the right to self-defence against terrorist actors could be exercised in another state absent "substantial," or for that matter any involvement of the state 
with the attacks. Canada sent a similarly worded letter in March 2015 (UNSC 2015a), and Australia followed suit in September 2015 (UNSC 2015c). The phrasing that states "must be able to defend themselves ..." is of interest; it suggests an acknowledgement that the justification pushes the boundaries of the existing law and may in fact be better read as a statement of what the law ought to be.

Other coalition members that participated in operations in Syria refrained from making explicit legality claims (Starski 2016, 28-29), and a significant number of coalition states, including Belgium, Denmark, and the Netherlands, confined their participation to Iraq, which had consented to strikes in its territory (Starski 2016, 30). The September 2014 letter sent by the United Kingdom, for example, stated only that it was "taking measures in support of the collective self-defence of Iraq as part of international efforts led by the United States" and that it fully supported international strikes on IS "sites and military strongholds in Syria" (UNSC 2014c). France, which commenced air strikes in Syria in September 2015, offered only a general Article 51 justification, noting that it had "taken actions involving the participation of military aircraft in response to attacks carried out by ISIL from the territory of the Syrian Arab Republic" (UNSC 2015b). A large number of states remained altogether silent on the commencement of strikes against IS in Syria, while a handful of states expressed various kinds of objections (Starski 2010, 31-32).

The situation shifted again, however, after the IS attacks in Paris of 13 November 2015. Shortly after the attacks, the Security Council adopted resolution 2249, which determined that the IS constitutes a "global and unprecedented threat to international peace and security," in part because of "its control over significant parts and natural resources across Iraq and Syria" (UNSC 2015d, preamble). Resolution 2249 went on to call upon states "to take all necessary measures, in compliance with international law, ... on the territory under the control of ISIL ... in Syria and Iraq" (UNSC 2015d, para. 5).

In the Security Council debates after the adoption of the resolution, the French representative stated that the French military action in Syria, which it had previously justified as collective selfdefence, "can now also be characterized as individual self-defence, in accordance with Article 51" (UNSC 2015e, 2). France did not, however, invoke the "unwilling or unable" standard advanced in the US Article 51 letter from 2014. The same is true for the UK, which began to extend its military strikes to IS sites in Syria in December 2015. Although Prime Minister David Cameron invoked the "unwilling or unable" doctrine in the House of Commons in November 2015 (UK House of Commons 2015, Column 1491), the official statement of the British position, contained in the letter of 3 December 2015 to the Security Council, stated only that the UK was "taking necessary and proportionate measures against ISIL/Daesh in Syria, as called for by the Council in resolution 2249" (UNSC 2015f). 
Resolution 2249 was ambiguous in that it neither authorized the use of force under Chapter VII of the UN Charter nor offered an explicit endorsement of various states' assertions of selfdefence (Akande and Milanovic 2015; Wood 2016), much less of the "unwilling or unable" standard. Nonetheless, it played an important role in the continuing process of applicatory contestation over the scope of the right to self-defence. Particularly significant in this context was the justification offered by Germany for joining in the collective self-defence operations against the IS in Syria. Germany's letter to the Security Council of 10 December 2015 refers to resolution 2249 and goes on to state that "ISIL has occupied a certain part of Syrian territory over which the [Syrian] Government ... does not at this time exercise effective control" so that states are "justified under Article 51 ... to take necessary measures of self-defence, even without the consent of the [Syrian] Government" (UNSC 2015g). Belgium sent a similarly phrased Article 51 letter in June 2016 (UNSC 2016).

Two aspects of this approach to justification stand out. First, Germany and Belgium emphasized the IS control over parts of Syrian territory and the resultant lack of effective control by Syria of the relevant areas. Second, like a number of other countries, Germany and Belgium tied their self-defence arguments to resolution 2249. In other words, the German and Belgian Article 51 letters provided a far narrower justification than the "unwilling or unable" standard advanced by the United States, a justification that some commentators have likened to a "lex-ISIL", a special set of rules not applicable to other terror networks who lack "a territorial basis and military forces capable of making and stabilizing territorial gains" (von Bernstorff 2016). What is more, by connecting this argument to a Security Council resolution that had confirmed IS control over parts of Syria, the German and Belgian letters appear to suggest that a determination by the Council of the preconditions for self-defence (with the multilateral deliberation that Council involvement entails) is required in the case of non-state actor attacks that cannot be attributed to a state (Hakimi and Katz Cogan 2016). Four other states (Denmark, the Netherlands, Norway and the United Kingdom) linked their Article 51 justifications to resolution 2249 (Hakimi and Katz Cogan 2016), albeit not in the specific way that Germany and Belgium had done.

The legal picture at the end of May 2017, then, is that some shifts in the material and rhetorical practices concerning the right to self-defence have occurred. Whereas before 11 September 2011, and even up until the recent events involving the IS, there was still considerable support for the idea that only attacks by a state or attributable to a state give rise to a right to use force in self-defence (Hakimi 2015, 19), it now seems generally accepted that non-state actors can commit armed attacks (Wood, 1). The threshold for attributing non-state actor attacks to a state seems to have been lowered, with a more generous understanding of "substantial 
involvement" having gained ground (Becker-Lorca 2012, 36-39; Kammerhofer 2015, 5-6; TiboriSzabó 2016, 86).

However, the preconditions for the exercise of the right to self-defence against a non-state actor attack undertaken from a third state, but not attributable to that state, remain contested (Hakimi 2015; Hakimi and Katz Cogan 2016; Starski 2016). According to an October 2016 survey of state attitudes toward the "unwilling or unable" standard ten states (US, UK, Germany, The Netherlands, Czech Republic, Canada, Australia, Russia, Turkey and Israel) explicitly endorsed the test, while three states (Belgium, Iran, South Africa) were doing so implicitly; nine states' positions were classified as ambiguous, and four states were found to object (Chachko and Deeks 2016). A closer look suggests, however, that the survey overstates the support for the "unwilling or unable" standard and that a consistent pattern of practice concerning the right to self-defence against non-state actors is in fact difficult to discern, even among the states that have participated in military actions against IS in Syria.

Germany and Belgium's positions arguably should not be classified as endorsements, explicit or implicit, of the "unwilling or unable" test, but as advancing a more specific, narrower standard. That narrower standard may have some traction in UK and US reasoning as well. The United Kingdom's Attorney General, in a January 2017 speech, did not specifically endorse the "unwilling or unable" test. Instead, he noted that "a number of states" considered "self-defence is available as a legal basis where the State from whose territory the actual or imminent attack emanates is unwilling or unable to prevent the attack or is not in effective control of the relevant part of its territory" (UK AG, 2017; 11). Even the United States, in a December 2016 "legal and policy framework" document, allowed that "inability perhaps can be demonstrated most plainly where, for example, the State has lost or abandoned effective control over the portion of its territory" from which the non-state actor operates. In turn, "unwillingness might be demonstrated where, for example, a State is colluding with or harboring a terrorist organization operating from within its territory and refuses to address the threat posed by the group" (US 2016; 10).

The Czech Republic expressed uncertainty as to whether the "unwilling or unable" standard was "part of the customary law international law requirement of necessity" (quoted in Chachko and Deeks 2016, 16), as the United States appears to suggest (US 2016; 10). The new Canadian government announced in February 2016 that Canada would cease its air strike operations in Syria (Canada 2016), and Russia appears to have retreated from its endorsement of the "unwilling or unable" test (Chachko and Deeks 2016, 19), at least in the context of the Syrian situation. Finally, it is worth adding that the "Non-Aligned Movement," a loose grouping of 120 
states, at its September 2016 meeting, reiterated its view that " ... Article 51 of the UN Charter is restrictive and should not be re-written or re-interpreted" (NAM 2016, para. 25.2).

In short, it is doubtful that the rather mixed practice of a limited number of states can suffice to shift customary law in the face of the silence of a majority of states on the operations against IS in Syria (Corten 2016, 785-791; Starski 2016; Tibori-Szabó 2015, 86), and the explicit preference of 120 states that the self-defence norm remain a narrow exception. This general preference underscores that silence on a specific invocation of an exception, even by powerful states, cannot be assumed to manifest consent, but can just as readily be interpreted as reluctance to endorse the expansive claim (Starksi 2016). This reading is reinforced by the relationship between the exception and the primary rule of the non-use of force. If a prohibition on the use of force is the starting proposition, it is exceptions that have to be explicitly justified, not the primary rule.

\subsection{The Right to Self-Defence Against Non-state Actors: Norm Robustness, Contestation and Interactional Law}

World events evidently play a role in prompting and shaping change in law. The rise of the IS, a global terror network with extraordinary resources and capacity to inflict harm, marked a key moment in the long-standing contestation around the scope of the right to self-defence. Furthermore, as one commentator put it, IS "barbarism seems to have opened the floodgates" for acceptance of the "unwilling or unable" standard (von Bernstorff 2016, 3). However, whether or not this standard has emerged as a globally shared understanding is one question. Whether that standard has become part of international law is quite another. Our interactional law framework enables us to undertake a finely grained assessment of the "robustness" of the international legal rules on the use of force, and to explore why, even as the scope of the right to self-defence has expanded, the "unwilling and unable standard" remains contested. We directly address Zimmermann and Deitelhoff's challenge to explain "how ... [the] ebbs and flows [of legal norms] come about" (Zimmermann and Deitelhoff 2016, 4).

Our premise is that Article 2(4) remains the primary legal norm of the Charter's framework on the use of force. Notwithstanding the assertion of some commentators (Franck 1970, 2004; Glennon 2002, 2005), there is no evidence that the validity of the prohibition on the use of force is widely challenged today (Gray 2008). By contrast, our survey of salient developments shows that the right to self-defence, enshrined in Article 51 of the Charter, has been subject to repeated cycles of applicatory contestation. This contestation has widened the scope of the right to self-defence in a number of respects. Yet, we do not share the assessment that, as a result of the state practice since 1945, the Charter's use of force framework is "better seen as 
permissive than constraining" (Hurd 2016, 1). The right to self-defence continues to operate as an exception to the prohibition on the use of force, rather than simply a "permission" to use force that "also implies constraints" (Hurd 2016, 14).

We suggest that the widely shared understanding concerning the prohibition on the use of force as primary "rule" and the right to self-defence as "exception" is evident in the very fact that attempts to widen the right to self-defence have been entangled in persistent applicatory contestation, framed by insistence on narrow, verifiable parameters for the exception. This "rule-exception" example demonstrates why it is analytically necessary to examine norms in relation to other norms with which they interact. As we detail below, the interplay between the prohibition and the exception affects the extent to which each meets the requirements of legality.

We now turn to an assessment of the right to self-defence against non-state actors through the lens of the criteria of legality, detailed above, paying particular attention to the contestation of the "unwilling or unable" standard.

The "unwilling or unable" standard raises questions, first, in relation to the requirement that legal norms be "general" - that they be "rules," rather than ad hoc decisions. While framed in apparently general terms, in practice the "unwilling and unable standard" singles out a certain category of state. Several commentators have observed that the test has been applied only to states in the Global South (Ahmed 2013; Tzouvala 2016). It establishes a "legal framework for ... the semi-periphery" (von Bernstorff 2016,4 ) harkening back to the standard of "civilization" in $19^{\text {th }}$ century international law (Becker-Lorca 2012) that enabled European states to accord non-European states a lesser legal status because of how they were "internally organized" (Tzouvala 2016, 2). This critique is powerful to the extent that the effect of the "unwilling or unable" standard can be to single out even "willing" states on the basis of relative incapacity (Tibori-Szabó 2015,89 ). The sovereignty of such states would be compromised, for they would be presented with the choice of either consenting to operations in their territories or suffering the intervention under the banner of self-defence (Tibori-Szabó 2015, 95). The recent attempts to limit, or displace, the nascent "unwilling or unable" standard are aimed in part at mitigating the standard's impact on the generality requirement of the criteria of legality. The focus on territorial control of the non-state actor, affirmed by a Security Council finding, serves to render highly exceptional the circumstances in which a state that is not supporting the non-state actor can be exposed to self-defence measures on its territory.

On the standard account, customary law is generated and maintained by a consistent, widespread and representative practice, accompanied by states' conviction that they are legally 
bound to conduct themselves in accordance with the norm (opinio juris) (ICJ 1969, paras. 7374). Norm-shifts, then, occur when a new standard is being embraced by consistent and widespread practice, accompanied by opinio juris or, as we have argued, practices of legality. Since much of the content of Article 51 of the UN Charter is provided by customary law, the treaty provision is subject to the inherent dynamism of this process. Although customary law nonetheless tends to be relatively stable, shifting only incrementally, the diffuse, fluid nature of the process makes it harder to identify the precise point at which a new law has been promulgated (Brunnée 2017). In the current context, however, it is safe to say that the scope of the right the self-defence against non-state actor attacks remains highly contested. Therefore, the "unwilling or unable" standard has not been promulgated.

Whereas questions of retro-activity are not engaged by the debates concerning the right to selfdefence, the requirement of clarity has played a central role. Indeed, much of the struggle surrounding the scope of the right to self-defence revolves around efforts to maintain criteria that are capable of objective assessment. To be sure, the formulation of the right to selfdefence must be sufficiently open-meshed to accommodate a diversity of situations and allow for evolution. Nonetheless, the capacity for objective assessment, which is a key aspect of clarity and predictability, has been at issue in virtually all the discussions about expanding the right, in contexts that go beyond the case of non-state actors

For example, in his famous account of the Cuban Missile Crisis, the former US State Department Legal Adviser, Abram Chayes, explained why the United States was not relying on the right to self-defence in the following terms: "... to expand ... [the right to anticipatory] self-defence to include threatening deployments that do not have imminent attack ... as their probable outcome ... is to make the occasion for forceful response essentially a question for unilateral decision that would not only be formally unreviewable, but not subject to intelligent criticism either" (Chayes 1974, 65). Similarly, the ICJ's narrow, state-centric, definition of armed attack was designed not only to limit recourse to armed force, but also to maintain objectively ascertainable (attribution) standards. And, in the current debate about self-defence against non-attributable non-state actor attacks, it is precisely the fact that the lack of clarity of the "unwilling or unable" test provides greater room for self-serving claims (Ahmed 2013, 14-16; Becker-Lorca 2012, 92; Deeks 2012, 488; Bethlehem 2013, 584; Tibori-Szabó 2015, 88) that has been of concern. Moreover, the alternative justification, turning on a finding by the Security Council of territorial control of the non-state actor, is designed to provide criteria that are more amenable to verification.

The criterion of non-contradiction shines the spotlight on the relationship between the components of the Charter's use of force framework that we flagged earlier in this paper. 
Chayes' observations in the context of anticipatory self-defence apply with equal force in the debate about the scope for self-defence against non-state actor attacks: a wide "construction of 'armed attack' could not help but weaken ... normative checks" on how states behave (Chayes 1974, 65). We would add that an overbroad reading of the self-defence exception would threaten to hollow out the primary rule, contradicting it and amounting to validity contestation. We suggest, therefore, that the scope of the right to self-defence has practical implications, of course, but it also affects the legality of the entire use of force framework.

This point has been made elsewhere in powerful terms, with one commentator asking whether embracing the "unwilling or unable" standard would entail removing the legal constraints on inter-state violence, and whether it would produce "a creature that can still be called law," or a "zombie" (von Bernstorff 2016, 2, 6). We would suggest again that the protracted contestation surrounding the "unwilling or unable" standard tends to confirm that these concerns are not merely those of academic commentators, but are shared by a great number of states. In other words, the inherent contradiction between an expansive right to self-defence and the prohibition on the use of force is among the legality factors that are holding back the acceptance of the "unwilling or unable" standard as international law. Arguably, the same can be said for the tension between this standard and the foundational legal principles of sovereignty and non-intervention (Becker-Lorca 2012, 91-92). The alternative proposal of Germany and Belgium would mitigate the contradiction by focusing on the territorial control exercised by the non-state group. It could also be understood as seeking to engage in deliberation under Chapter VII so as to further reduce the tension with the prohibition on the use of force, and the sovereignty and non-intervention principles. Chapter VII, after all does envisage limiting all three principles through Security Council authorization.

Legal norms should make reasonable demands, not asking the impossible of those to whom they are addressed. We noted at the outset of this paper that a sweeping prohibition on the use of inter-state force would be practically (and politically) unthinkable without appropriate exceptions. Now we can expand on why this point also has legal implications. Turning our attention to the right to self-defence, it is apparent that an overly narrow construction of the right might be seen as asking states to do the impossible: to suffer attacks and tolerate urgent threats. Of course, the matter is not as black-and-white as this, as a narrow reading of the right to self-defence would not deprive states of the ability to respond, but only of the ability to respond by using force without involvement of the Security Council. Nonetheless, the international political and security environment that we have traced, ranging from the limited capacity of the Security Council to discharge its collective security function to the rise of highly dangerous non-state actors with broad reach, illustrates that real world changes affect not only strategic calculations, but can also impact on the legality of the existing rule framework. 
The requirement that legal rules make reasonable demands is one of the criteria that highlights the need for a recalibration of the law. This need will manifest itself as well when overly stringent or inapt restrictions lead to increasing disregard of the rule in practice (Becker-Lorca $2012,90,93)$. However, it is important to note that, in the context of the "unwilling or unable" standard, the reasonableness requirement also pulls in the opposite direction. After all, to the extent that the standard captures states that are willing but unable to take sufficient measures precluding terrorist attacks from their territory, it makes it impossible for these states to avoid foreign military intervention (Becker-Lorca 2012, 13). The alternative justification advanced by Germany and Belgium, once again, would serve to strike a balance, in this case between competing "impossibilities." It would increase the scope for self-defence, but reduce the circumstances in which states would be subject to the exercise of the right in their territories.

A similar tension plays out with regard to the requirement of congruence. At the moment there is no consistent practice of legality that would support the "unwilling or unable" standard, for the reasons we have outlined. Yet, our analysis also serves to highlight how legality requirements can pull in opposite directions. For example, while the requirement of clarity may militate in favour of a narrowly defined standard, a change in conditions (e.g. the rise of nonstate actors like IS) may lead a previously reasonable standard to become overly narrow, as the requirement that legal rules avoid impossible demands illustrates. As existing legal standards become "unreasonable," practice may begin to deviate from the standard, depriving it of the congruence required to maintain the law (Becker-Lorca 2012, 93). In short, our framework reveals that norm robustness in law may rest precisely in the push and pull of the legality requirements and the manner in which they both enable and discipline contestation and legal norm change.

Although the "unwilling or unable" standard has been invoked by a small group of states for some time, there does not currently exist a widespread, consistent and representative practice of legality concerning the standard. Indeed, our analysis of the standard in relation to the criteria of legality suggests that such a practice is unlikely to develop. However, the disparate practices surrounding the standard do have implications for the criterion of constancy over time: the legality of the rules on self-defence is undercut by the resultant lack of predictability.

\section{Conclusion}

Our interactional understanding of international law contributes strong insights into the robustness of legal norms, connecting to the growing inquiry of IR scholars into norm robustness generally. In our case study on self-defence against non-state actors, treaty law and 
customary law interact. Our study highlights a crucial, and more broadly relevant, point: in assessing the robustness of legal norms, focussing on continuing practices of legality is more revealing than merely assessing rates of treaty ratification. Norms are not static artifacts, but are continuously supported, re-fashioned or destroyed through practice, both material and rhetorical.

Through a detailed examination of the inter-state legal framework on the use of force, and specifically the "unwilling and unable" justification for self-defence against non-state actors, we have shown how contestation operates in law. Material acts matter. Responses to acts matter. Rhetorical acts matter. Silence matters, but cannot necessarily be interpreted as consent. In other words, applicatory contestation is central to law. Our approach is particularly revealing of how applicatory contestation challenges, but more commonly supports existing legal normative frameworks. It can also stabilize law in a dynamic equilibrium. Particular elements of the law may be altered through applicatory contestation, but that contestation is bounded by the requirements of legality.

We do not suggest that validity contestation is impossible in law. It will occur when underlying social norms collapse or are replaced, or when applicatory contestation escalates to a point where rhetorical or material practices of norm challengers no longer meet the requirements of legality. In the latter case, if the increasingly transgressive practices are not resisted, or are even embraced by a significant number of actors, the boundary between applicatory and validity contesation is crossed. Yet, this process is highly disciplined, requiring the engagement of many states. A few powerful actors cannot alone accomplish this shift from applicatory to validity contestation. More often than not, continuing applicatory contestation, as a practice of legality, will adjust the law so that the impulse to fundamentally question its underlying social premises is minimized. Validity contestation is made harder. The centrality of applicatory contestation, in turn, supports law's tendency to promote stability, and shows how stability is itself dynamic.

Our case study deals with applicatory contestation, but examines an instance of applicatory contestion that could lead to validity contestation. That is because the rhetorical and material practices of the proponents of the "unwilling or unable" standard transgress several requirements of legality. These practices do not currently attract sufficient support to change the law, and we argue that this lack of support is due in part to the rule-exception dynamic at play. We demonstrate that it is often unhelpful to focus analysis on single legal norms, especially in circumstances involving such a dynamic. We have shown that when applicatory contestation of the exception implies validity contestation of a broadly supported primary rule, the strength of that rule is likely to constrain expansion of the exception. Separately, our 
examination of applicatory contestation of legal norms indicates that whenever such contestation transgresses several requirements of legality, it is likely to be resisted.

In sum, our interactional approach demonstrates that specific requirements of legality account for the distinctive traits of legal norms, and helps illuminate how they discipline legal contestation in a particular way, distinguishing it from other forms of contestation. To directly answer Zimmermann and Deitelhoff $(2016,6)$, seeing legal contestation as part of norm robustness is not "tautological." Continuing practices of legality constantly, and typically incrementally, reshape law while maintaining a basic level of stability, thereby accounting for law's relative robustness. 


\section{Bibliography: [Check Reference Completeness and Style]}

Adler, Emanuel. 2005. Communitarian International Relations: The Epistemic Foundations of International Relations. Routledge.

Ahmed, Dawood I. 2013. "Defending Weak States against the "Unwilling or Unable" Doctrine of Self-Defense." Journal of International Law and International Relations 9: 1-37.

Akande, Dapo, and Marko Milanovic. 2015. "The Constructive Ambiguity of the Security Council's ISIS Resolution." EJIL: Talk! (21 November 2015); at http://www.ejiltalk.org/theconstructive-ambiguity-of-the-security-councils-isis-resolution/ (accessed 4 November 2016).

Becker-Lorca, Arnulf. 2012. "Rules for the "Global War on Terror": Implying Consent and Presuming Conditions for Intervention." New York University Journal of International Law \& Policy 45: 1-95.

Berman, Paul Schiff. 2012. Global Legal Pluralism: A Jurisprudence of Law Beyond Borders. Cambridge: Cambridge University Press.

von Bernstorff, Jochen. 2016. "Drone Strikes, Terrorism and the Zombie: On the Construction of an Administrative Law of Transnational Executions." European Society of International Law (ESIL) Reflections, Vol. 5, Issue 7; at http://www.esil-sedi.eu/node/1368 (accessed 4 November 2016).

Bethlehem, Daniel. 2013. "Principles of Self-Defence - A Brief Response." American Journal of International Law 107: 579-585.

Bianchi, Andrea. 2016. International Law Theories: An Inquiry into Different Ways of Thinking (Oxford: Oxford University Press).

Brunnée, Jutta. 2017. "Sources of International Environmental Law: Interactional Law," forthcoming in Oxford Handbook on the Sources of International Law, edited by Samantha Besson and Jean d'Aspremont, [??]. Oxford: Oxford University Press.

Brunnée, Jutta and Stephen J. Toope. 2010. Legitimacy and Legality in International Law: An Interactional Account. Cambridge: Cambridge University Press.

. 2011. "Interactional International Law and the Practice of Legality," in International Practices, edited by Emanuel Adler and Vincent Pouliot, 108-135. Cambridge: Cambridge University Press.

. 2017. "Interactional Legal Theory, the International Rule of Law and Global Constitutionalism," forthcoming in Handbook of Global Constitutionalism," edited by Anthony Lang and Antje Wiener, [??]. Edward Elgar. 
Chachko, Elena and Ashley Deeks. 2016. "Who is on Board with 'Unwilling and Unable'?" Lawfare (10 October 2016); at https://www.lawfareblog.com/who-board-unwilling-or-unable (accessed 4 November 2016).

Chayes, Abram. 1974. The Cuban Missile Crisis. Oxford: Oxford University Press.

Corten, Olivier. 2010. The Law Against War: The Prohibition on the Use of Force in Contemporary International Law (Oxford and Portland, OR: Hart Publishing).

. 2016. "The 'Unwilling or Unable' Test: Has it Been, and Could it be, Accepted?" Leiden Journal of International Law 29: 777-799.

Deeks, Ashley. 2012. "“Unwilling or Unable": Toward a Normative Framework for Extraterritorial Self-Defense." Virginia Journal of International Law 52: 483-550.

Finnemore, Martha, and Kathryn Sikkink. 1998. "International Norm Dynamics and Political Change." International Organization 52: 887-917.

Franck, Thomas. 1970. "Who Killed Article 2(4)? Or: Changing Norms Governing the Use of Force by States." American Journal of International Law 64: 809-37.

. 2003. "What Happens Now? The United Nations After Iraq." American Journal of International Law 97: 607-20.

Fuller, Lon L. (1969). The Morality of Law, revised edition (New Haven: Yale University Press).

Gardam, Judith. 2004. Necessity, Proportionality and the Use of Force by States. Cambridge: Cambridge University Press.

Glennon, Michael J. 2002. "The Fog of Law: Self- Defense, Inherence, and Incoherence in Article 51 of the United Nations Charter." Harvard Journal of Law and Public Policy, 25: 539-558.

. 2005. “How International Rules Die." Georgetown Law Journal 93: 939-92.

Gray, Christine. 2008. International Law and the Use of Force. $3^{\text {rd }}$ ed. Oxford: Oxford University Press.

Hakimi, Monica. 2015. "Defensive Force against Non-State Actors: The State of Play." International Law Studies 91: 1-31.

and Jacob Katz Cogan. 2016a. "A Role for the Security Council on Defensive Force?" EJIL: Talk! (21 October 2016); at http://www.ejiltalk.org/a-role-for-the-security-council-ondefensive-force/ (accessed 4 November 2016). 
. 2016b. "The Two Codes on the Use of Force." European Journal of International Law 27 (2): 257-291.

Hurd, lan. 2014. "Torture and the Politics of Legitimation in International Law," in Legitimacy of international human rights regimes, edited by Andreas Follesdal, Johan K. Schaffer, and Geir Ulfstein, 165-189. Cambridge: Cambridge University Press.

. 2016. "The Permissive Power of the Ban on War." Forthcoming in European Journal of International Security; at https://www.cambridge.org/core/journals/european-journal-ofinternational-security/article/the-permissive-power-of-the-ban-onwar/946C793E42731DB9F99CC3E47A71EF7F/core-reader (accessed 10 November 2016).

Kammerhofer, Jörg. 2015a. "The Resilience of the Restrictive Rules on Self-Defence", in Oxford Handbook of the Use of Force in International Law, edited by Marc Weller, 627-48. Oxford: Oxford University Press.

. 2015b. "Positivism," in Oxford Bibliographies: International Law, edited by Anthony Carty. Oxford: Oxford University Press. DOI: 10.1093/obo/9780199796953-0059.

Koskenniemi, Martti. 2011. "The Mystery of Legal Obligation." International Theory 3: 319-325.

Kratochwil, Friedrich, and John G. Ruggie. 1986. "International Organization: A State of the Art on an Art of the State." International Organization 40: 753-75

Panke, Diana, and Ulrich Petersohn. 2012. "Why International Norms Disappear Sometimes." European Journal of International Relations 18: 719-42.

Percy, Sarah. 2014. "The Unimplemented Norm," in Implementation and World Politics, edited by Alexander Betts and Phil Orchard, 68-84. Oxford: Oxford University Press.

Postema, Gerald J. 1994. "Implicit Law." Law and Philosophy 13: 361. Reprinted in Willem J. Witteveen and Wibren van der Burg, eds., Rediscovering Fuller: Essays on Implicit Law and Institutional Design (Amsterdam University Press, 1999), 255-275.

Pound, Roscoe. 1923. Interpretations of Legal History. [Place/Publisher??].

Price, Richard. 2004. "Emerging Customary Norms and Anti-Personnel Landmines," in The Politics of International Law, edited by Christian Reus-Smit, 106-30. Cambridge: Cambridge University Press.

. 2006. "Detecting Ideas and Their Effects," in The Oxford Handbook of Contextual Political Analysis, edited by Robert E. Goodin and Charles Tilly, 252-65. Oxford: Oxford University Press. 
Reinold, Theresa and Zürn, Michael. 2014. "'Rules about rules' and the endogenous dynamics of international law: Dissonance reduction as a mechanism of secondary rule-making." Global Constitutionalism 3: 236-273.

Ruys, Tom. 2010. 'Armed Attack' and Article 51 of the UN Charter: Evolutions in Customary Law and Practice. Oxford: Oxford University Press.

Sandholtz, Wayne. 2009. "Explaining International Norm Change," in International Norms and Cycles of Change, edited by Wayne Sandholtz and Kevin Stiles (New York: Oxford University Press) 1-26.

. 2016. "Norms Don't Die. They Get Replaced" [this volume].

Scharf, Michael. 2016. "How the War Against ISIS Changed International Law." Case Western Reserve Journal of International Law 48: 15-63.

Starski, Paulina. 2016. "Silence within the Process of Normative Change and Evolution of the Prohibition on the Use of Force - Normative Volatility and Legislative Responsibility." Max Planck Institute for Comparative Public and International Law (MPIL) Research Paper Series, No. 2016-20; at https://papers.ssrn.com/sol3/papers.cfm?abstract id=2851809 (accessed November 4, 2016).

Stürchler, Nikolas. 2007. The Threat of Force in International Law. Cambridge: Cambridge University Press.

Tibori-Szabó, Kinga. 2015. "The 'Unwilling or Unable' Test and the Law of Self-defence," in Fundemental Rights in International and European Law: Public and Private Law Perspectives, edited by Christophe Paulussen et al, 73-97. Berlin - Heidelberg: Springer.

Trapp, Kimberley. 2015. "Actor-pluralism, the 'turn to responsibility' and the jus ad bellum: 'unwilling or unable' in context." Journal on the Use of Force and International Law 2: 199-222.

Tzouvala, Ntina. 2016. "TWAIL and the "Unwilling or Unable" Doctrine: Continuities and Ruptures." American Journal of International Law (AJIL) Unbound (17 March 2016); at https://www.asil.org/blogs/symposium-twail-perspectives-icl-ihl-and-intervention-twail-and"unwilling-or-unable"-doctrine (accessed November 4, 2016).

Weller, Marc. 2015. "Striking ISIL: Aspects of the Law on the Use of Force." American Society of International Law (ASIL) Insights, Vol. 19, Issue 5; at https://www.asil.org/insights/volume/19/issue/5/striking-isil-aspects-law-use-force (accessed November 4, 2016). 
Wenger, Etienne. 1998. Communities of Practice: Learning, Meaning, and Identity (Cambridge: Cambridge University Press.

Wiener, Antje. 2004. "Contested Compliance: Interventions on the Normative Structure of World Politics." European Journal of International Relations 10: 189-234.

. 2014. A Theory of Contestation. Heidelberg: Springer.

Wood, Michael. 2016. "The Use of Force in 2015 With Particular Reference to Syria." Hebrew University of Jerusalem Legal Studies Research Paper Series, No. 16-05; at https://papers.ssrn.com/sol3/papers.cfm?abstract_id=2714064 (accessed 4 November 2016).

Zemanek, Karl. 2013. "Armed Attack." Max Planck Encyclopedia of Public International Law, edited by Rüdiger Wolfrum.

Zimmermann, Lisbeth and Nicole Deitelhoff. 2016. "Norms under challenge: Unpacking the Dynamics of Norm Robustness." [THIS VOLUME].

Judicial Decisions and Official Documents:

Canada (Office of the Prime Minister), "Prime Minister sets new course to address crises in Iraq and Syria and impacts on the region" (8 February 2016), at http://pm.gc.ca/eng/news/2016/02/08/prime-minister-sets-new-course-address-crises-iraqand-syria-and-impacts-region (accessed 16 November 2016).

International Court of Justice (ICJ), North Sea Continental Shelf cases (Germany v. Denmark, Germany v. Netherlands) (Merits), (1969) ICJ Rep 3 (North Sea Continental Shelf case).

ICJ, Case concerning military and paramilitary activities in and against Nicaragua (Nicaragua $v$. United States of America) (Merits), Judgment of 26 November 1984, (1984) ICJ Rep 392 (Nicaragua case).

ICJ, Legal consequences of the construction of a wall in the Occupied Palestinian Territory, Advisory Opinion of 9 July 2004, (2004) ICJ Rep 163 (Wall Advisory Opinion).

ICJ, Case concerning armed activities on the territory of the Congo (Democratic Republic of the Congo v. Uganda), Judgment of 19 December 2005, (2005) ICJ Rep 116-220 (Armed Activities case).

ICJ, Application of the Convention on the Prevention and Punishment of the Crime of Genocide (Bosnia and Herzegovina v. Serbia and Montenegro), Judgment of 26 February 2007, [????]. 
International Criminal Tribunal for the Former Yugoslavia (ICTY) - Appeals Chamber, Prosecutor v Dusko Tadić, Case No. IT-94-1-A, Judgment of 15 July 1999.

Non-Aligned Movement (NAM), $17^{\text {th }}$ Summit of Heads of State or Government of the NonAligned Movement, Final Document, 17-18 September 2016, NAM 2016/CoB/DOC.1. Corr.1; at http://cns.miis.edu/nam/documents/Official Document/XVII-NAM-Summit-Final-OutcomeDocument-ENG.pdf (accessed 24 April 2017).

United Kingdom, Attorney General Speech at International Institute for Strategic Studies: "The modern law of self-defence," 11 January 2017, at https://www.justsecurity.org/wpcontent/uploads/2017/01/United-Kingdom-Attorney-General-Speech-modern-law-of-selfdefense-IISS.pdf (accessed 24 April 2017).

United Kingdom, House of Commons Debates, 26 November 2015, Column 1489-94, at http://www.publications.parliament.uk/pa/cm201516/cmhansrd/cm151126/debtext/1511260001.htm\#15112625000002 (accessed 24 April 2017).

United Nations General Assembly (UNGA). 1970. Declaration on Principles of International Law Concerning Friendly Relations and Cooperation Among States in accordance with the Charter of the United Nations, Resolution 2625 (XXV) of 24 October 1970 (Friendly Relations Declaration).

. 1974. Resolution 3314 (XXIX) of 14 December 1974 (Definition of Aggression).

United Nations Security Council (UNSC). 2001a. Resolution 1368 of 12 September 2001.

2001b. Resolution 1373 of 28 September 2001.

- 2001c. Letter dated 7 October 2001 from the Permanent Representative of the United States of America to the United Nations addressed to the President of the Security Council, UN Doc. S/2001/946.

. 2001d. Letter dated 7 october 2001 from the Chargé d'affaires a.i. of the Permanent Mission of the United Kingdom of Great Britain and Northern Ireland to the United Nations addressed to the President of the Security Council, UN Doc. S/2001/947.

. 2014a. Letter dated 23 September 2014 from the Permanent Representative of the United States of America to the United Nations addressed to the Secretary-General, UN Doc. S/2014/695.

2014b. Letter dated 25 September 2014 from the Permanent Representative of the United Kingdom of Great Britain and Northern Ireland to the United Nations addressed to the Secretary-General, UN Doc. S/2014/851. 
. 2015a. Letter dated 31 March 2015 from the Chargé d'affaires a.i. of the Permanent Mission of Canada to the United Nations addressed to the President of the Security Council, UN Doc. S/2015/221.

. 2015b. Identical letters dated 8 September 2015 from the Permanent Representative of France to the United Nations addressed to the Secretary-General and the President of the Security Council, UN Doc. S/2015/745.

. 2015c. Letter dated 9 September 2015 from the Permanent Representative of Australia to the United Nations addressed to the Secretary-General, UN Doc. S/2015/693.

. 2015d. Resolution 2249 (2015), UN Doc. S/RES/2249 (20 November 2015).

2015e. $7565^{\text {th }}$ Meeting (Threats to international peace and security caused by terrorist acts), UN Doc. S/PV.7565 (20 November 2015).

. 2015f. Letter dated 3 December 2015 from the Permanent Representative of the United Kingdom of Great Britain and Northern Ireland to the United Nations addressed to the President of the Security Council, UN Doc. S/2015/928.

2015g. Letter dated 10 December 2015 from the Chargé d'affaires a.i. of the Permanent Mission of Germany to the United Nations addressed to the President of the Security Council, UN Doc. S/2015/946.

2016. Letter dated 7 June 2016 from the Permanent Representative of Belgium to the United Nations addressed to the President of the Security Council, UN Doc. S/2016/523.

United States, Report on the Legal and Policy Frameworks Guiding the United States' Use of Military force and Related National Security Operations (December 2016), at https://www.hsdl.org/?abstract\&did=798033 (accessed 24 April 2017). 